Global Journal of Human Resource Management

Vol.8, No.2, pp.64-77, June 2020

Published by ECRTD-UK

Print ISSN: 2053-5686(Print), Online ISSN: 2053-5694(Online)

\title{
THE EFFECT OF HR PRACTICES ON JOB LOYALTY THROUGH PSYCHOLOGICAL EMPOWERMENT AND JOB SATISFACTION IN PT. $X$
}

\author{
Rintani Dyan Pangastuti \\ Master of Management, Universitas Pelita Harapan Surabaya Campus \\ Oliandes Sondakh \\ Master of Management, Universitas Pelita Harapan Surabaya Campus \\ Hananiel Mennoverdi Gunawan \\ Master of Management, Universitas Pelita Harapan Surabaya Campus
}

\begin{abstract}
In Indonesia, the growth of the number of construction companies is apparently not in line with the growth of experts. This study aims to analyze the effect of HR Practices on Job Loyalty through Psychological Empowerment and Job Satisfaction at PT. X. This study using quantitative methods with a sample used is 80 employees with the criteria have worked more than two years, have a minimum high school education, at the staff level. Data processing in this study uses SPSS 22.0. From the results of data processing it was found that HR Practices (Training and Reward) had a significant influence on Psychological Empowerment (Job Competence, Job Autonomy, Job Impact). Job Competence and Job Impact does not have a significant effect on Job Satisfaction. Job Autonomy has a significant influence on Job Satisfaction. Job Satisfaction has a significant effect on Job Loyalty.
\end{abstract}

KEYWORD: HR practices, psychological empowerment, job satisfaction, job loyalty

\section{BACKGROUND}

Infrastructure development and macroeconomic development have a reciprocal relationship. This is due to the infrastructure development gives rise to economic expansion through a multiplier effect. If infrastructure development is hampered, the economic growth rate will be weaker. The development of infrastructure affects the price of market needs because of the weak trade network. Inadequate infrastructure also affects the attractiveness of the investment climate in Indonesia. Foreign investors are reluctant to invest because they are worried with the issue of high transportation costs (www.indonesia-investments.com accessed July 23, 2019).

The Indonesian government is aware of the importance of improving the state'sinfrastructure so that the investment and business climate becomes more attractive. However, to build infrastructure in Indonesia is not easy. The government is looking for new approaches in its efforts to achieve breakthroughs in infrastructure development, one of the ways is to increase the required budget (www.indonesiainvestments.com accessed July 23, 2019).

The growth of infrastructure development has made the construction sector one of the industries to improve positive performance in a slowing economic growth. Based on 
data from the Central Statistics Agency, annual economic growth in the third quarter in 2018 was $5.17 \%$, lower than the position in the second quarter in 2018 of $5.27 \%$. Meanwhile, the growth of the construction sector recorded a slight increase to $5.79 \%$ in the third quarter in 2018 compared to the position in the second quarter in 2018 of $5.73 \%$ (economy.bisnis.com accessed July 23, 2019).

In Indonesia, the number of construction companies also continues to grow from year to year. However, the growth in the number of construction companies was not balance with the growth of experts. According to Ruslan, the Chairperson of the National LPJK, the number of certified experts in construction industry in Indonesia reached 196,017. The number consists of 82,554 young experts, 105,844 intermediate experts, and 7,619 key experts (www.ekonomi.bisnis.com accessed July 23, 2019). Zali Yahya, Secretary General of the Indonesian Contractors Association (AKI), stated that most of the organizations that oversee contractors were still stumbling over certification issues in dealing with the ASEAN Economic Community (AEC) or the ASEAN market. This is related to the awareness of contractor companies to carry out labor certification or certification for technicians (engineers) is still low (www.bisnis.tempo.co accessed July 23, 2019).

Basuki Hadimuljono as the Minister of Public Works and Public Housing stated that the quality of human resources in construction services must also be improved, this also relates to Law No. 2 of 2017 on Construction Services, where every worker who works in the construction sector must have a certificate of work competency (www.beritasatu.com accessed July 23, 2019). This indicates that every construction company must immediately improve itself. In an effort to improve itself, human resources are a very important factor for the survival of construction companies. Experienced workforce is an important asset for construction companies, therefore construction companies must ensure that employees who have the knowledge and experience in the company will continue working in the company.

The experienced workforce will remain in a company if they satisfy in their work (Motlou et al, 2016). In this regard, Maric et al (2011) states that developing satisfaction can reduce the level of employee turnover and that is an important aspect for the company as well as the outstanding employees who might be valuable employee for the company.

According to Solomon (1992) Job Loyalty is a willingness to stay in the organization. According to Mowday, Porter and Steers (1982), Job Loyalty is a manifestation of organizational commitment, the relative measure of individuals' identification and particula organizational involvement. The Loyalty Research Center (1990) states that Job Loyalty is a condition where employees are not actively seeking for other jobs and are not responsive to any existing offers.

Job Satisfaction is a comfortable feeling and positive experience that employees feel at work (Bakotić et al, 2013). According to Opkara (2002) Job Satisfaction is the result of various factors such as salary, promotion, work itself, supervision, relationships with colleagues and opportunities for promotion.HR Practices is a process of attracting, 
motivating, and retaining employees to ensure the survival of the organization (Schuler and Jackson, 1987). Several aspects of HR Practices encourage employees to work better to improve organizational performance (Snell and Dean, 1992; Pfeffer, 1998). Training is an effort made by the company to improve employee performance on the current work or any work that relates to it (Bernadin and Russell, 2013). Kinicki (2007) states that Training is an activity aimed at improving performance to benchmarks according to standards. Therefore, Training is not only a way to improve employee capabilities but also a way to make the best use of human resources in an organization. Reward is understood as the total amount of financial and non-financial compensation or the total remuneration given to employees in return for labor or services provided at work (Anku et al, 2018). Armstrong (2006) defines rewards management as the formulation and implementation of strategies and policies with the ultimate goal of rewarding employees fairly, equitably and consistently, which must be aligned with organizational values for the organization to realize strategic objectives.

According to Spreitzer (2007), Psychological Empowerment refers to a set of psychological states that are needed for individuals to feel a sense of control related to their work, psychological perspective that is focused on how employees experience their work, and individual beliefs about their role in the organization.Job Competence is knowledge, abilities, and skills that can be identified and can be measured by the characteristics possessed by human resources needed to support performance (HRXML, 2006). Competence is the ability of individuals to consistently integrate the knowledge, skills and judgment needed to carry out their work safely, ethically, and effectively (Moghabghab et al, 2018).

Job Autonomy is the level of freedom an employee has regarding when and how the employee complete the job (Fornes, Rocco \& Wollard, 2008). Breaugh (1985) defines work method autonomy as flexibility in choosing procedures or methods to accomplish tasks, work scheduling autonomy as a feeling in which a person can control the order or time of his work, and work criteria autonomy as freedom in making changes to the indicators or standards used for evaluating someone's performance.Job Impact is a sense of progress towards individual goals and beliefs that their actions make a difference in their organization, which contributes to employee involvement (Stander and Rothman, 2010). Job Impact describes organizational involvement and reflects whether individuals feel that they make a difference in their organization (Spreitzer et al., 1997).

This research was made to find out about how HR practices effects Job Loyalty through Psychological Empowerment, and Job Satisfaction. In this study, we can find out how HR Practices affect Psychological Empowerment. Through this research, we can also find out how Psychological Empowerment can affect Job Satisfaction, and how Job Satisfaction affects Job Loyalty.

\section{LITERATURE REVIEW}

Mahmudi and Kargaran (2016) stated that abilities and skills help performance and efficiency for the organization, so training and development are long-term investments that can be utilized by organizations. From this study it is known that Training has a 
very significant influence on Competence which is an attribute of Empowerment. Woods (2010) states that technology skills, people skills, creativity, effectiveness by using various ways of communicating and self-confidence are important Job Competence for Training. This manajerial training research was done in a professional and non-professional manner from various departments in the hotel industry. Based on this, a hypothesis can be developed as follows:

Hypothesis 1: Trainings have a significant effect on Job Competency

Voegtlin et al. (2015) developed research on how to empower employees through training, and in that study note that training has a significant influence on autonomy which is one of the Empowerment dimensions. Hewagama et al. (2019) states that Training has a significant influence on Job Autonomy. Based on this, a hypothesis can be developed as follows:

Hypothesis 2: Trainings have a significant effect on Job Autonomy

Zahrani et al (2012) developed research about influence of Anttencendent Supporting Organization (Participation, Training, Culture, Incentive, Leadership and Teamwork) on Psychological Empowerment (Meaningfull, Competence, Self-Determination, Impact). Based on this research known that Training which is atribut of Anttencendent Supporting Organization has a positive relationship with Job Impact which is atribut of Psychological Empowerment. Rehg et al. (2012) concluded that training and development have a strong influence on the success of a worker in adjusting and making an impact in the various cultures that exist within an institution. Based on this, a hypothesis can be developed as follows:

Hypothesis 3: Trainings have a significant effect on Job Impact

Haulfort et al. (2002) studied the effect of Performance Contingent Reward on Competence, Perceived Autonomy, and Intrinsic Motivation for undergraduate students who take additional credits suggests a similar conclusion. Namely that PerformanceContingent Reward has a positive relationship on Perceived Competence. Gkorezis and Petridou (2012) stated that Extrinsic Rewards had a significant influence on Psychological Empowerment including Competence in private company's employees. Based on this, a hypothesis can be developed as follows:

Hypothesis 4: Rewards has a significant effect on Job Competence

Haulfort et al. (2002) separates between Affective Autonomy and Decisional Autonomy. In this study it is known that Reward has a positive impact on Decisional Autonomy. Reward has a significant influence in relation to Job Autonomy (Hewagama et al. 2019). Based on this, a hypothesis can be developed as follows:

Hypothesis 5: Rewards has a significant effect on Job Autonomy 
Gkorezis, P., \& Petridou, E. (2011) examined the impact of bundle Rewards (information, Job Security, and Recognition) on Psychological Empowerment (Meaning, Competence, Self-Determination, Impact) suggesting that Reward has a positive relationship on Job Impact which is one of the dimensions of Psychological Empowerment. Based on this, a hypothesis can be developed as follows:

Hypothesis 6: Rewards has a significant effect on Job Impact

Landry and Whillans (2019) who examined the power of rewards for job satisfaction through psychological satisfaction needs in this case are Competency Need, Autonomy Need, and Related Need states that there is a positive correlation in the relationship between psychological satisfaction in this case is Competence in Job Satisfaction. Hewagama et al. (2019) stated that Reward has a significant influence in relation to Job Impact. Based on this, a hypothesis can be developed as follows:

Hypothesis 7: Job Competence has a significant effect on Job Satisfaction

Rizwan et al (2014) in a study in the industrial and banking sectors in Punjab (Bahawalpur) stated that Job Autonomy has a positive and significant influence on the creation of Employee Satisfaction. Naqvi et al. (2013) in a study conducted in the Fast Food sector stated that Job Autonomy has a significant influence on Job Satisfaction. Based on this, a hypothesis can be developed as follows:

Hypothesis 8: Job Autonomy has a significant effect on Job Satisfaction

Abdullah et al. (2015) which states that Job Impact has a significant influence on Intrinsic Job Satisfaction and Extrinsic Job Satisfaction. According to Tetik (2016) the Psychological Empowerment aspect in this case is the Impact of a positive and significant effect on Job Satisfaction. Based on this, a hypothesis can be developed as follows:

Hypothesis 9: Job Impact has a significant effect on Job Satisfaction

Sutanto and Perdana (2016) has developed research on variables that preceded the existence of Employees Loyalty. Based on this research, known that satisfaction of leadership, satisfaction of compensation and satisfaction of work environment has a significant influence on employees loyalty. Pandey and Khare (2012) in their research stated the same thing, namely that Job Satisfaction has a significant influence on Job Loyalty. Based on this, a hypothesis can be developed as follows:

Hypothesis 10: Job Satisfaction has a significant effect on Job Loyalty 


\section{RESEARCH MODEL}



Figure 1. Research Model

\section{RESEARCH METHOD}

This research was conducted at a construction company in Surabaya. This research is a quantitative study, in which the questionnaire is distributed to employees at PT. X. The questionnaire distributed was divided into two parts, the first part was to find out the demographic condition of the respondents, the second part was to find out HR Practices, namely, Psychological Empowerment, Job Satisfaction, Job Loyalty. The questionnaire was measured using a 1-5 Likert scale, number 1 reflects strongly disagree to the statement and number 5 reflects strongly agreed to the statement provided. The questionnaires were distributed to 125 employees of PT. X. However, only 80 questionnaires can be used in this study. The criteria set for the respondents are the ones who are a permanent employee at PT. X, respondents, have worked for more than two years, high school minimum education, and are at the staff level. Data processing using SPSS version 22.0.

\section{Data Processing Results}

Demographically, the data collected consisted of 40 women and 40 men. The respondents with the age range of 18-25 years are 2 people, ages 26-35 years are 47 people, ages 36-45 years are 27 people, and ages 46-60 years are 4 people.

\section{Research Results}

Table 1. Effect HR Practices on Job Competence

\begin{tabular}{|c|c|c|c|c|c|c|c|}
\hline \multirow[b]{2}{*}{ Model } & \multicolumn{2}{|c|}{$\begin{array}{l}\text { Unstandardized } \\
\text { Coefficients }\end{array}$} & \multirow{2}{*}{\begin{tabular}{|l|l|}
$\begin{array}{l}\text { Standardized } \\
\text { Coefficients }\end{array}$ \\
Beta \\
\end{tabular}} & \multirow[b]{2}{*}{ t } & \multirow[b]{2}{*}{ Sig. } & \multicolumn{2}{|c|}{$\begin{array}{l}\text { Collinearity } \\
\text { Statistics }\end{array}$} \\
\hline & $\mathrm{B}$ & Std. Error & & & & Toler & VIF \\
\hline $1 \quad$ (Constant) & 1.414 & .451 & & 3.133 & .002 & & \\
\hline TR & .285 & .111 & .270 & 2.574 & .012 & .830 & 1.204 \\
\hline $\mathrm{RW}$ & 378 & .105 & .376 & 3.586 & .001 & .830 & 1.204 \\
\hline
\end{tabular}

a. Dependent Variable: JC 
From the linear regression analysis, conducted to determine the relationship between the effect of Training and Reward on Job Competence, the result is shown in table 1. From table 1 it is known that the value of the effect of Training on Job Competence is 0.012 , this value is smaller than 0.05 and can be indicated that Training has a significant effect on Job Competence, and this means that H1 is accepted. The value of the effect of the Reward on Job Competence is 0.001 this value is less than 0.05 and can be interpreted that the Reward has a significant effect on Job Competence, and this means that $\mathrm{H} 4$ is accepted

Table 2 Effect of HR Practices on Job Autonomy

\begin{tabular}{|c|c|c|c|c|c|c|c|}
\hline \multirow[b]{2}{*}{ Model } & \multicolumn{2}{|c|}{$\begin{array}{l}\text { Unstandardized } \\
\text { Coefficients }\end{array}$} & \multirow{2}{*}{\begin{tabular}{|l|} 
Standardized \\
Coefficients \\
Beta \\
\end{tabular}} & \multirow[b]{2}{*}{$\mathrm{t}$} & \multirow[b]{2}{*}{ Sig. } & \multicolumn{2}{|c|}{$\begin{array}{l}\text { Collinearity } \\
\text { Statistics }\end{array}$} \\
\hline & $\mathrm{B}$ & Std. Error & & & & Tolerance & VIF \\
\hline $1 \quad$ (Constant) & 1.273 & .455 & & 2.797 & .007 & & \\
\hline TR & .366 & .112 & .337 & 3.273 & .002 & 830 & 1.204 \\
\hline RW & .352 & .106 & .341 & 3.314 & .001 & .830 & 1.204 \\
\hline
\end{tabular}

a. Dependent Variable: JA

From the linear regression analysis conducted, to determine the relationship between the effect of Training and Reward on Job Autonomy, the results are shown in Table 2. From Table 2 it is known that the value of the effect of Training on Job Autonomy is 0.002 , this value is smaller than 0.05 and can be interpreted that Training has a significant effect on Job Autonomy, and this means that $\mathrm{H} 2$ is accepted. The value of the effect of the Reward on Job Autonomy is 0.001, this value is less than 0.05 and it can be interpreted that the Reward has a significant effect on Job Autonomy, and this means that $\mathrm{H} 5$ is accepted.

Table 3 Effect of HR Practices on Job Impact

\begin{tabular}{|c|c|c|c|c|c|c|c|}
\hline \multirow[b]{2}{*}{ Model } & \multicolumn{2}{|c|}{$\begin{array}{l}\text { Unstandardized } \\
\text { Coefficients }\end{array}$} & \multirow{2}{*}{\begin{tabular}{|l|}
$\begin{array}{l}\text { Standardized } \\
\text { Coefficients }\end{array}$ \\
Beta \\
\end{tabular}} & \multirow[b]{2}{*}{ t } & \multirow[b]{2}{*}{ Sig. } & \multicolumn{2}{|c|}{$\begin{array}{l}\text { Collinearity } \\
\text { Statistics }\end{array}$} \\
\hline & $B$ & Std. Error & & & & Tolerance & VIF \\
\hline $1 \quad$ (Constant) & 1.721 & 448 & & 3.837 & .000 & & \\
\hline TR & .356 & 110 & 346 & 3.231 & .002 & 830 & 1.204 \\
\hline RW & .260 & .105 & .266 & 2.486 & .015 & .830 & 1.204 \\
\hline
\end{tabular}

a. Dependent Variable: JI

From the linear regression analysis conducted, to determine the relationship between the effect of Training and Reward on Job Impact, the results are shown in Table 3. From Table 3 show that the value of the effect of Training on Job Impact is 0.002 , this value is smaller than 0.05 and can be This means that Training has a significant effect on Job Impact, and this means that $\mathrm{H} 3$ is accepted. The value of the effect of Reward on Job Impact is 0.015 , this value is less than 0.05 and can be interpreted that Reward has a significant effect on Job Impact, and this means that H6 is accepted. 
Table 4 Effect of Psychological Empowerment on Job Satisfaction

\begin{tabular}{|c|c|c|c|c|c|c|c|}
\hline \multirow[b]{2}{*}{ Model } & \multicolumn{2}{|c|}{$\begin{array}{l}\text { Unstandardized } \\
\text { Coefficients }\end{array}$} & \multirow{2}{*}{\begin{tabular}{|l} 
Standardized \\
Coefficients \\
Beta \\
\end{tabular}} & \multirow[b]{2}{*}{$t$} & \multirow[b]{2}{*}{ Sig. } & \multicolumn{2}{|c|}{$\begin{array}{l}\text { Collinearity } \\
\text { Statistics }\end{array}$} \\
\hline & $\mathrm{B}$ & Std. Error & & & & Tolerance & VIF \\
\hline $1 \quad$ (Constant & 1.496 & .403 & & 3.711 & .000 & & \\
\hline $\mathrm{JC}$ & .077 & .146 & .078 & .525 & .601 & .385 & 2.598 \\
\hline JA & .368 & .151 & .386 & 2.435 & .017 & .339 & 2.947 \\
\hline JI & .175 & .163 & .173 & 1.072 & .287 & .325 & 3.074 \\
\hline
\end{tabular}

a. Dependent Variable: JS

From the linear regression analysis conducted, to determine the relationship between the influence of Job Competence, Job Autonomy and Job Impact on Job Satisfaction obtained the results shown in Table 4. From Table 4 it is known that the value of the effect of Job Competence on Job Satisfaction is 0.601, this value is greater of 0.05 and can be interpreted that Job Competence does not have a significant effect on Job Satisfaction, and this means that $\mathrm{H} 7$ is rejected. The value of the effect of Job Autonomy on Job Satisfaction is 0.017 , this value is less than 0.05 and can be interpreted that Job Autonomy has a significant effect on Job Satisfaction, and this means that H8 is accepted. The value of the effect of Job Impact on Job Satisfaction is 0.287, this value is greater than 0.05 and can be interpreted that Job Impact does not have a significant effect on Job Satisfaction, and this means that H9 is rejected.

Table 5 Effect of Job Satisfaction on Job Loyalty

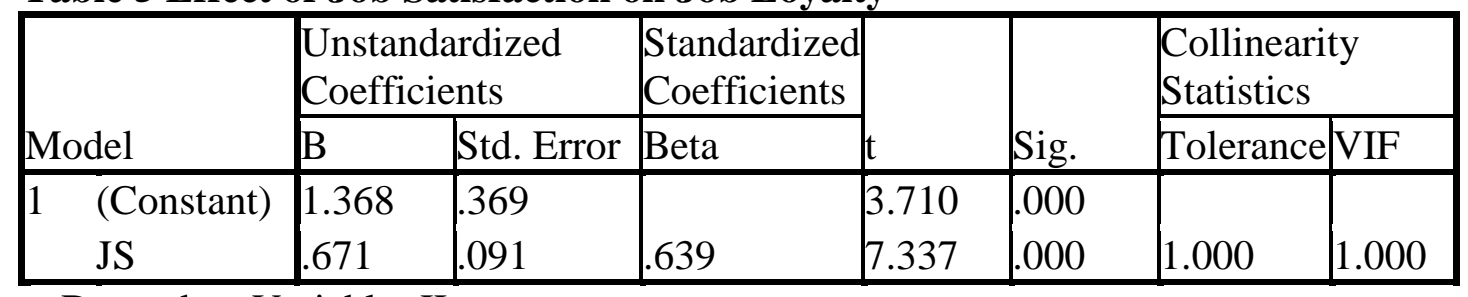

a. Dependent Variable: JL

From the linear regression analysis conducted, to determine the relationship between the effect of Job Satisfaction on Job Loyalty obtained, the results are shown in Table 5. From Table 5 it is known that the value of the effect of Job Satisfaction on Job Loyalty is 0,000 , this value is smaller than 0.05 and can be This means that Job Satisfaction has a significant effect on Job Loyalty, and this means that H10 is accepted.

Table 6 The Mean of Variable

\begin{tabular}{|l|l|l|}
\hline No & Variable & Average Mean \\
\hline 1 & Training & 3,796 \\
\hline 2 & Reward & 3,845 \\
\hline 3 & Job Competence & 3,950 \\
\hline 4 & Job Autonomy & 4,017 \\
\hline 5 & Job Impact & 4,072 \\
\hline 6 & Job Satisfaction & 3,990 \\
\hline 7 & Job Loyalty & 4,047 \\
\hline
\end{tabular}


Based on the calculation of the average value of each variable, it is known that the three indicators of Training has a mean of 3,796. This results shows that employees feel that the company has provided training in accordance with what is needed by employees to be able to complete their work. On the reward variable, from the three indicators studied, an average of 3,845 is known. This shows that employees feel that the company has given rewards in accordance with the needs felt by employees. In the Job Competence variable the mean is 3,950. This shows that employees feel that they have sufficient ability to do and complete their work. Job Autonomy has a mean of 4,017, this shows that the company has given confidence to employees to do and complete their work freely without or with minimal supervision. The average of the Job Impact variable is 4.072, this means that employees feel that their existence has an impact on the company. The average Job Satisfaction is 3,990, this shows if the employee feels satisfied working at the company. Job Loyalty has an average of 4.047, this shows that employees have Job Loyalty in the company.

In the analysis of the effect of Training and Reward on Job Competence obtained Adjusted R2 number of 0.279 or $27.9 \%$ shows that the percentage contribution of the influence of Training (TR), Reward (RW) to Job Competence (JC) is $27.9 \%$ which means that Training (TR) and Reward (RW) are able to explain 27.9\% Job Competence, while the remaining $72.1 \%$ is influenced by other variables not included in this research model. F test results indicate a significance value of 0,000 , this means that research models that aim to test the effect of Training (TR), Reward (RW) on Job Competence (JC) can be accepted so that it can be concluded jointly Training (TR), Reward (RW ) affect Job Competence (JC).

In the analysis of the effect of Training and Reward on Job Autonomy obtained an Adjusted Figures R2 of 0.306 or $30.6 \%$ shows that the percentage contribution of the Training (TR) and Reward (RW) influence on Job Autonomy (JA) is 30.6\%, which means that Training (TR) and Reward (RW) are able to explain $30.6 \%$ of Job Autonomy, while the remaining $69.4 \%$ is influenced by other variables not included in this research model. F test results indicate a significance value of 0,000 , this means that research models that aim to test the effect of Training (TR) and Reward (RW) on Job Autonomy (JA) are acceptable.

In the analysis of the effect of Training and Reward on Job Impact, the Adjusted R2 number of 0.248 or $24.8 \%$ shows that the percentage contribution of the Training, Reward effect on Job Impact is $24.8 \%$, which means that Training and Reward is able to explain $24.8 \%$ Job Impact, while the remaining $75.2 \%$ is influenced by other variables not included in this research model.F test results show a significance value of 0,000 , this means that research models that aim to test the effect of Training, Reward on Job Impact can be accepted so that it can be concluded jointly with Training, Reward can affect Job Impact.

In the analysis of the influence of Job Competence, Job Autonomy, and Job Impact on Job Satisfaction, the Adjusted R2 figure is 0.328 or $32.8 \%$, indicating that the percentage contribution of Job Competence, Job Autonomy and Job Impact impact on Job Satisfaction is $32.8 \%$. means that Job Competence, Job Autonomy, and Job Impact 
can explain $32.8 \%$ Job Satisfaction, while the remaining $67.2 \%$ is influenced by other variables not included in this research model. test results show a significance value of 0,000 , this means that research models that aim to test the effect of Job Competence, Job Autonomy, and Job Impact on Job Satisfaction can be accepted so that it can be concluded together Job Competence, Job Autonomy, and Job Impact can affect Job Satisfaction.

In the analysis of the effect of Job Satisfaction on Job Loyalty obtained R2 numbers of 0.408 or $40.8 \%$ shows that the percentage contribution of the influence of Job Satisfaction to Job Loyalty is $40.8 \%$ which means that Job Satisfaction is able to explain $40.8 \%$ of Job Loyalty, while the remaining $59.2 \%$ is influenced by other variables not included in this research model. F test results show a significance value of 0,000 , this means that research models that aim to test the effect of Job Satisfaction can be accepted so that it can be concluded that Job Satisfaction can affect Job Loyalty.

Overall, the first test to test the effect of Training and Reward on Job Competence shows a strong correlation. Reward provides a positive and significant effect on Job Competence. The biggest influence on Job Competence is given by Rewards with a standardized beta coefficient of 0.376 . This is in line with research conducted by Gkorezis and Petridou (2012) stating that Extrinsic Rewards has a significant influence on Competence which is one of the attributes of Psychological Empowerment. Training also has a positive and significant influence on Job Competence. The standardized beta coefficient is 0.270 . This is consistent with research developed by Mahmudi and Kargaran (2016) which states that Training / Education has a very significant influence on Competence which is one of the attributes of Empowerment.

The second test examines the effect of Training and Reward on Job Autonomy. From this analysis it is known that the effect of training and reward on Job Autonomy shows a strong correlation. Training and Reward provides a positive and significant impact on Job Autonomy. The biggest influence on Job Autonomy is given by Rewards with a standardized beta coefficient of 0.341 and Training of 0.337 . This is in line with research developed by Hewagama et al (2019) which suggests that Reward and Training has a significant influence in relation to Job Autonomy on workers in the hospitality sector.

The third test examines the effect of Training and Reward on Job Impact. From this analysis it is known that the effect of training and reward on Job Impact shows a strong correlation. Training has a positive and significant impact on Job Impact. Training provides a greater influence when compared to Rewards for Job Impact. The standardized beta training coefficient is 0.346 . This is consistent with the research developed by Voegtlin et al. (2015) which states that Training has a significant influence on Impact which is one of the attributes of Empowerment. Although the effect is smaller than Training, Reward has a positive and significant impact on Job Impact. The standardized value of the beta Reward coefficient of 0.266 on Job Impact. This is in line with research developed by Hewagama et al. (2019) which states that Reward has a significant influence in relation to Job Impact in research conducted on employees in the hospitality sector. 
The fourth test examines the effect of Job Competence, Job Autonomy, Job Impact on Job Satisfaction. From this analysis it is known that the influence of Job Competence, Job Autonomy, and Job Impact on Job Satisfaction shows a strong correlation. Job Autonomy gives a positive and significant effect on Job Satisfaction with a standardized beta coefficient of 0.386. These results are in line with the study of Naqvi et al. (2013) in the Fast Food sector states that Job Autonomy has a significant influence on Job Satisfaction.

The effect of Job Competence on Job Satisfaction is positive but not significant, with a standardized beta coefficient of 0.078. This is in line with research developed by Saif and Saleh (2013) who examined the effect of Empowerment on Job Satisfaction on employees in private hospitals in Jordan who stated that Competence which is one of the attributes of Empowerment has a positive but not significant effect on Satisfaction. Job Impact has a positive but not significant effect on Job Satisfaction. The standardized beta coefficient is 0.173 . This is in line with the results of research developed by Hewagama et al (2019) who conducted research on hotel staff in Srilanka, stating that Job Impact had no significant effect in its direct relationship with Job Satisfaction.

The fifth model shows that Job Satisfaction has a positive and significant effect on Job Loyalty with a standardized beta coefficient of 0.639 . This explains that there is a strong correlation. It can be concluded that the strength of the relationship between Job Satisfaction (JS) and Job Loyalty (JL) is high. This finding is in line with the statement of Pandey and Khare (2012) in their research which suggests that Job Satisfaction has a significant influence on Job Loyalty.

\section{CONCLUSIONS AND RECOMMENDATIONS}

The results of this study suggest that Job Satisfaction has a positive and significant effect on Job Loyalty. It means that Job Satisfaction is important to reach Job Loyatly. Companies should pay attention on it, and find the way to improve the Job Satisfaction. The research model shows that job satisfaction is formed from psychological empowerment. All aspects of Psychological Empowerment have a positive influence on Job Satisfaction, but only Job Autonomy has a significant influence on Job Satisfaction, while the effect given by Job Competence and Job Impact on Job Satisfaction is not significant. Job satisfaction is influenced by psychological empowerment, it means companies should find the ways to increase the influence of psychological empowerment, especially in the area of job competence and job impact. Companies should find the ways for employees who have high competence and a large impact on their work to feel satisfaction at work. The aspects of HR Practices in this case are Training and Reward has a positive and significant influence on the aspects of Psychological Empowerment in this case are Job Competence, Job Autonomy, and Job Impact.

Companies should pay attention to every aspect that can improve Job Loyalty in the company. Not only the factors that have been mentioned in this study, but can also pay attention to other factors such as work environment, employee relationships, leadership, self determination, job security, promotion, teamwork or other factors. Companies 
should be aware of the current salary in the industry by comparing with competing companies. Companies should also provide affordable benefits, such as providing transportation/ shuttle for the employees. Another effort would be providing gathering event for employees and their family periodically. This way, employees will feel that the company cares about them and their families.

Future research can also broaden the scope of respondents to be studied, or conduct research in companies that are different from current research. In addition, it is expected to also be able to use the Structural Equational Model (SEM) software AMOS 16.0 in further research.

\section{References}

Abdullah, Abdul Ghani Kanesan., Tareq Ziad Almadhoun., Ying-Leh Ling.(2015). Psychological Empowerment, Job Satisfaction And Commitment Among Malaysian Secondary School Teachers. Asian Journal of Educational Research. Asian Journal of Educational ResearchVol. 3, No. 3 pp 34-42

Anku, J.S., Bless K.A., Mawutor, K.G. (2018). Concept of Reward Management, Reward System And Corporate Efficiency. International Journal of Economics, Commerce and Management Vol VI (2) Page 621-637. United Kingdom

Armstrong, M. (2006). A Handbook of Human Resource Management (10th ed.). London: Kogan Page Limited.

Bakotić, Danica.,TomislavBabić. (2013). Relationship between Working Conditions and Job Satisfaction: The Case of Croatian Shipbuilding Company. International Journal of Business and Social Science. Vol. 4 No. 2. Pp 206-213.

Breaugh, J. A. (1985). The measurement of work autonomy. Human Relations, 38(6), 551-570. doi: 10.1177/001872678503800604

Gkorezis Panagiotis, Eugenia Petridou. (2012). The effect of extrinsic rewards on public and private sector employees'psychological empowerment: a comparative approach. The International Journal of Human Resource Management. Vol. 23, No. 17, Page 3596-3612

Gkorezis, P., \&Petridou, E. (2011). The Impact Of Rewards On Empowering Public Nurses. Health services management research, 24(2), 55-59. doi:10.1258/hsmr.2010.010004

Hewagama, Gayani., Peter Boxall, Gordon Cheung, Ann Hutchison. 2019. Service recovery through empowerment? HRM, Employee Performance and Job Satisfaction in Hotels. International Journal of Hospitality Management 81 page $73-82$

Houlfort Nathalie, Richard K, Mireille J, Am'elie N.V, Natasha L. (2002). The Impact of Performance-Contingent Rewards on Perceived Autonomy and Competence. Motivation and Emotion, Vol. 26, No. 4. Page 279-295.

HR-XML Consortium Competencies Schema

Kinicki, K. (2007). A Theory of Reasoned Action : Applications and Implications.

Landry Thibault, A., \& Whillans, A. (2019). The Power of Workplace Rewards: Using Self-Determination Theory to Understand Why Reward Satisfaction Matters for Workers Around the World. Compensation \& Benefits Review. Page 1-26 
Mahmudi, R. KhodayidanJavad M. Kargaran. (2016). The effect of in-service training on empowerment of staff at the University of Tabriz. International Journal Of Humanities And Cultural Studies. Mei 2016 Hal 2001-2007.

Marič, Miha., Marko Ferjan., Vlado Dimovski., Matej Černe. (2011). Job Satisfaction and Loyalty to the Organization. 30th International Conference on Organizational Science Development Future Organization. March 23rd- 25th, 2011. Portorož, Slovenia.

Moghabghab, R., Tong, A., Hallaran, A., \& Anderson, J. (2018). The Difference Between competency and Competence: A Regulatory Perspective. Journal of Nursing Reulation, 9(2), 54-59.doi:10.1016/s2155-8256(18)30118-2

Mowday, R.T., Porter, L.W., and Steers, R.M. (1982), Employeeoriganization linkages. New York: Academic Press

Motlou, Reuben Gibb., Suveera Singh, Anis Mahomed Karodia. 2016. An Evaluation Of The Impact Of Job Satisfaction On Employee Retention At Lonmin Rowland Shaft North West Province. Kuwait Chapter of Arabian Journal of Business and Management Review. Vol. 5, No.10. pp 15-49.

Naqvi, S. R., Ishtiaq, M., Kanwal, N., \& Ali, M. (2013). Impact of Job Autonomy on Organizational Commitment and Job Satisfaction: The Moderating Role of Organizational Culture in Fast Food Sector of Pakistan. International Journal of Business and Management, 8(17), 92-101.

Opkara JO (2002). The Impact of Salary Differential On Managerial Job Satisfaction. A Study Of The Gender Gap And Its Implications For Management Education And Practice In A Developing Economy. J. Bus. Dev. Nation, 65-92.

Pandey, Chetna., Rajni Khare. (2012). Impact Of Job Satisfaction And Organizational Commitment On Employee Loyalty. International Journal of Social Science \& Interdisciplinary Research. Vol.1 Issue 8, August 2012, ISSN 22773630

Pfeffer, J., 1998. Seven practices of successful organizations, California Management Review, 40 (2): 96-124

Rizwan, Muhammad., Muhammad Imran Jamil. (2016). The Impact of the Job stress, Job Autonomy and Working Conditions on Employee Satisfaction. International Journal of Human Resource Studies.Vol. 4, No. 2 pp 196-207

Schuler, R.S., Jackson, S.E. (1987). Linking competitive strategies with human resource management practices. The Academy of Management Executive (1987-1989), 207-219

Snell, S. A., Dean, J.W. (1992). Integrated manufacturing and human resource management: A human capital perspective. Academy of Management journal, 35(3), 467-504.

Solomon, C.M. (1992, Sept.). The loyalty factor, Personnel Journal, 52-62.

Spreitzer, G.M., Kizilos, M.A., \&Nason, S.W. (1997). A dimensional analysis of the relationship between psychological empowerment, and effectiveness, satisfaction, and strain. Journal of Management, 23, 670-704.

Spreitzer, G.M. 2007.Taking Stock: A review of more than twenty years of research on empowerment at work. In The Handbook of Organizational Behavior, C. Cooper and J. Barling eds. Sage Publications 
Stander, Marius W., Sebastiaan, Rothmann. (2010). Psychological empowerment, job insecurity and employee engagement. SA Journal of Industrial Psychology. Vol 36, No 1 (2010)

Sutanto, Eddy M., Meiliana Perdana (2016). Antecedents Variable Of Employees Loyalty. Jurnal Manajemen Dan Kewirausahaan, Vol.18, No. 2, September 2016, pp 111-118

Tetik Nuray. (2016). The Effects of Psychological Empowerment on Job Satisfaction and Job Performance of Tourist Guides. International Journal of Academic Research in Business and Social Sciences. Vol. 6, No. 2, pp 221-239

The Loyalty Research Center: 317-465-1990, www.loyaltyresearch, pp 1-5

Voegtlin, Christian., Stephan A. Boehm., Heike Bruch. (2015). How to Empower Employees: Using Training to Enhance Work Units' Collective. International Journal of Manpower, 36 (3), 354 - 373

Ahli Konstruksi: Uji Kompetensi Jarak Jauh. Diakses 23 Juli 2019.

Web: $\quad$ https://ekonomi.bisnis.com/read/20190321/45/902814/ahli-konstruksi-ujikompetensi-jarak-jauh-diterapkan

Bisnis Beton Pracetak Semakin Menancap. Diakses 23 Juli 2019.

Web: https://ekonomi.bisnis.com/read/20180122/45/728978/bisnis-beton-pracetaksemakin-menancap

Hadapi Persaingan MEA, Kontraktor Indonesia Terancam?. Diakses 23 Juli 2019. Web: https://bisnis.tempo.co/read/732538/hadapi-persaingan-mea-kontraktorindonesia-terancam/full\&view $=$ ok

Infrastruktur di Indonesia. Diakses 23 Juli 2019.

Web: https://www.indonesia-investments.com/id/bisnis/risiko/infrastruktur/item381? Indonesia: Infrastruktur dan Pembangunan. Diakses 23 Juli 2019.

Web:https://faisalbasri.com/2015/09/18/indonesia-infrastruktur-danpembangunaPembuatan Sertifikat Keahlian Tenaga Teknik( SKA, SKT). Diakses 14 Agustus 2019.

Web: http://fakultasteknik.narotama.ac.id/2016/10/05/pembuatan-sertifikat-keahliantenaga-teknik-ska-skt/

Tahun 2019, Kementerian PUPR Prioritaskan Sertifikasi Tenaga Kerja Konstruksi. Diakses 23 Juli 2019. Web: https://www.beritasatu.com/ekonomi/538159/tahun2019-kementerian-pupr-prioritaskan-sertifikasi-tenaga-kerja-konstruksi

Sektor Konstruksi Makin Menggeliat. Diakses 23 Juli 2019.

Web: https://ekonomi.bisnis.com/read/20181105/45/856681/sektor-konstruksi-makinmenggeliat 